\title{
DIE GESIN AS FASET VAN TUISGEBASEERDE SORG VIR DIE VERSWAKTE MIV- EN VIGS-PASIËNT IN DIE MYNGEMEENSKAP VAN DIE NOORDWES PROVINSIE
}

\author{
R Steyn \\ M Cur \\ Skool vir Verpleegkunde, Noordwes-Universiteit, Potchefstroomkampus

\section{MP Koen} \\ $\mathrm{Ph} D$ \\ Mede-Professor, Skool vir Verpleegkunde, Noordwes-Universiteit, Potchefstroomkampus \\ Korresponderende outeur:vpkmpk@puk.ac.za

\section{MJS Williams} \\ M Cur \\ Senior Lektor, Skool vir Verpleegkunde, Noordwes-Universiteit, Potchefstroomkampus
}

Sleutelterme: verswakte MIV- en VIGS-pasiënt; myngemeenskap; gemeenskapsgebaseerde sorg; tuisgebaseerde sorg; gesin; gemeenskapsverpleegkundige; primêre versorger

\section{OPSOMMING}

Benewens die feit dat Suid-Afrika wêreldwyd uitgesonder word as die land met die hoogste voorkoms van VIGS, word die myngemeenskap van Suid-Afrika verder uitgesonder weens die hoë voorkomssyfer van MIV en VIGS in hierdie gemeenskap. In 'n poging om druk op die gesondheidsdienste te verlig het die klem van hospitaalgebaseerde sorg na tuisgebaseerde sorg van die verswakte MIV- en VIGS-pasiënt verskuif. As gevallebestuurder in diens van 'n mynmaatskappy, was die navorser gereeld in kontak met gesinne van verswakte MIV- en VIGS-pasiënte. Die navorser het ervaar dat hierdie gesinne nie voorberei is op die versorging van hierdie gesinslede nie. Na aanleiding hiervan asook die hoë voorkomssyfer van MIV en VIGS in die myngemeenskap was die doel van hierdie navorsing om die belewenisse van die gesinne van die verswakte MIV- en VIGS-pasiënte in die myngemeenskap van die Noordwes Provinsie ten opsigte van tuisgebaseerde sorg van hierdie pasiënt te verken en te beskryf. Die navorsing het ook ten doel gehad om tuisgebaseerde sorg aan die verswakte MIV-en VIGS-pasiënt te bevorder deur die formulering van riglyne vir die gemeenskapsverpleegkundige om gesinne te bemagtig ten opsigte van die lewering van tuisgebaseerde sorg aan die verswakte MIV-en VIGS-pasiënt. Die gepaste navorsingsontwerp vir die bereiking van bogenoemde doelstellings was ' $n$ kwalitatiewe navorsingsontwerp. Doelgerigte vrywillige steekproefneming is gedoen. Deelnemers is geïdentifiseer deur gebruik te maak van insluitingskriteria. Die steekproefgrootte is bepaal deur dataversadiging wat na tien onderhoude bereik is. Data-insameling het plaasgevind deur in-diepte onderhoude wat deur 'n enkelvraag ingelei is. Data-analise is onafhanklik deur die navorser en 'n medekodeerder gedoen. Die resultate van die navorsing was 'n beskrywing van die gesinne se belewenisse ten opsigte van die tuisversorging van die verswakte MIV-en VIGS-pasiënt in die myngemeenskap van die Noordwes Provinsie. Dit is onderverdeel in die gesin se belewenisse ten opsigte van: 1) die versorging van die verswakte MIV-en VIGS-pasiënt (fisieke, psigiese, sosiale en geestelike dimensie);2) die gemeenskap se reaksie teenoor die gesin (negatiewe en positiewe belewenisse) en 3) die sterwensproses. Uit hierdie resultate is gevolgtrekkings gemaak wat aanleiding gegee het tot die formulering van riglyne vir die gemeenskapsverpleegkundige om die gesin te bemagtig ten opsigte van die versorgingstaak van die verswakte MIV-en VIGS-pasiënt.

\section{SUMMARY}

Apart from the fact that South Africa is singled out worldwide as being the country with the highest incidence of HIV and AIDS, the mining community within South Africa is further implicated as having a high incidence of HIV and 
AIDS. In an attempt to alleviate pressure on health services, the emphasis has shifted from hospital-based care to home-based care of the debilitated HIV and AIDS patient. As a case manager employed by a mining company, the researcher has had regular contact with families of debilitated HIV and AIDS patients. The researcher experienced that these families are not prepared for caring for these family members. In consequence of this and of the high incidence of HIV and AIDS in the mining community the aim of this research was to explore and describe the experiences of the families of the debilitated HIV and AIDS patient in the mining community of the North-West Province with regard to home-based care of these patients. The research also aimed at promoting home-based care of the debilitated HIV and AIDS patient by formulating guidelines for the community nurse on the basis of which families can be empowered regarding the delivery of home-based care to the debilitated HIV and AIDS patient. The appropriate research design for the above-mentioned aims was a qualitative research design. Purposive voluntary sampling was done. Participants were identified by means of selection criteria. The sample size was determined by data saturation that was reached after ten interviews. Collection of data took place by means of in-depth interviewing that was introduced by a single question. The researcher and a co-coder independently analysed the data. The results of the research were a description of the experiences of the families relating to home-care of the debilitated HIV and AIDS patient in the mining community of the North West Province. It was categorised into the experiences of the family with regard to: 1) caring for the debilitated HIV and AIDS-patient (physical, psychological, social and spiritual dimension); 2) the community's reaction towards the family (positive and negative) and 3) the dying process. From these results conclusions were drawn that gave rise to the formulation of guidelines for the community nurse in order to empower the families for the task of caring for the debilitated HIV and AIDS patient.

\section{INLEIDING EN PROBLEEMSTELLING}

Met MIV en VIGS as 'n kommerwekkende stressor vir gesondheidsdienslewering in Suid-Afrika, het die behoefte ontstaan om tuisgebaseerde sorg as 'n alternatief vir hospitalisasie te ondersoek. Weens die potensiaal wat dit inhou ten opsigte van kostebesparing is daadwerklike pogings aangewend om tuisgebaseerde sorg te implementeer (Hansen, Woelk, Jackson, Kirkhoven, Hanjonjori, Maramba, Mutambirwa, Nolimande \& Vera, 1998:751; Schopper \& Walley, 1992:89; Haile, 2000:690; Schneider \& Russel, 2000:214). Met die hoë voorkoms van MIV en VIGS in veral die myngemeenskappe in Suid Afrika, naamlik tussen 20\% en 30\% (Williams \& Campbell, 1998:27), val die klem ook op tuisgebaseerde sorg van die verswakte MIV- en VIGS-pasiënt in die myngemeenskap. Die gesin is de facto- en gereeld de jure-versorgers wanneer ' $n$ gesinslid siek is of in die moeilikheid verkeer (Pequegnant \& Szapocznik, 2000:3), en die gemeenskapsverpleegkundige speel ook 'n belangrike rol by die tuisversorging van die verswakte MIV- en VIGS-pasiënt. Dit wil egter voorkom of tuisgebaseerde sorg aan die verswakte MIV- en VIGSpasiënt belemmer word deur gesinne wat onvoorbereid is ten opsigte van die versorging van die pasiënt, en dit blyk dat daar vir die gemeenskapsverpleegkundige geleentheid sou wees om 'n verskil te maak ten opsigte van die bemagtiging van hierdie gesinne. Ten einde die gemeenskapsverpleegkundige in staat te stel om suksesvol te wees in die bemagtiging van die gesinne, behoort wetenskaplik geformuleerde riglyne beskikbaar te wees. Daarom is dit belangrik om kennis te bekom aangaande die gesinne van die verswakte MIV- en VIGSpasiënt in die myngemeenskap se belewenis ten opsigte van tuisgebaseerde sorg. Dit het aanleiding gegee tot die volgende vrae:

- Hoe beleef gesinne van die verswakte MIV-en VIGS-pasiënt hul versorging van die verswakte MIV- en VIGS-pasiënt in die myngemeenskappe van die Noordwes Provinsie?

- Hoe kan gesinne van die verswakte MIV- en VIGS-pasiënt in die myngemeenskap bemagtig word sodat tuisgebaseerde sorg in die myngemeenskappe van die Noordwes Provinsie bevorder kan word?

\section{NAVORSINGSDOELSTELLINGS}

As deel van die groepnavorsingsprojek van die Skool vir Verpleegkunde oor omvattende gesondheidsdienslewering aan die MIV- en VIGS-pasiënt aan die Potchefstroomkampus van die Noordwes-Universiteit was die doelstellings, voortvloeiend uit die navorsingsvrae, soos volg:

- om die gesin van die verswakte MIV-en VIGS- 
pasiënt in die myngemeenskap se belewenis ten opsigte van tuisgebaseerde sorg van die verswakte MIV- en VIGS-pasiënt in die myngemeenskap te verken en te beskryf; en

- om tuisgebaseerde sorg aan die verswakte MIV- en VIGS-pasiënt in die myngemeenskap te bevorder deur die formulering van riglyne vir die gemeenskapsverpleegkundige om gesinne van verswakte MIV- en VIGS-pasiënte te bemagtig ten opsigte van die lewering van tuisgebaseerde sorg aan hierdie verswakte MIVen VIGS-pasiënte.

\section{DEFINIËRING VAN KONSEPTE}

\section{MIV en VIGS}

MIV (menslike immuniteitsgebrekvirus) is ' $n$ infeksie wat veroorsaak word deur een van twee tipes retrovirusse wat immuno-onderdrukking tot gevolg het. In reaksie op die indringing van hierdie virus vorm die liggaam teenliggaampies om die virus teen te staan. Sodra hierdie teenliggaampies in die mens se bloedstroom gevind word, is die persoon MIV-positief. VIGS is 'n multi-sistemiese toestand van ernstige immunoonderdrukking as gevolg van die menslike immuniteitsgebrekvirus waarvan opportunistiese infeksies, neoplasmas, neurologiese disfunksie en 'n verskeidenheid ander sindrome tipies is (Beers \& Berkow, 1999:1312; Fact sheets on HIV/AIDS, 2000:1).

\section{Myngemeenskap}

Die myngemeenskap is ' $n$ groep mense wat binne die geografiese grense van mynbedrywighede woon en spesifieke eienskappe en waardes deel. 'n Myngemeenskap sluit mynskagte met omliggende woongebiede in asook verdere woongebiede binne die geografiese grense wat nie uitsluitlik myneiendom is nie. Dit sluit ook hostelle, gesondheidsfasiliteite soos klinieke en hospitale, winkels en sosiale vergaderplekke in (Odendal \& Gouws, 2000:258; Williams, MacPhail, Taljaard, Gouws, Moema, Mzidume \& Rasego, 2000:353; Clark, 1996:6).

\section{Tuisgebaseerde sorg}

Tuisgebaseerde sorg is ' $n$ alternatief vir institusioneelgebaseerde sorg aan persone wat 'n behoefte aan versorging het. Hierdie sorg word gelewer wanneer die persoon tuis is en word deur informele versorgers, formele versorgers, vrywilligers en tradisionele versorgers voorsien. Informele tuisgebaseerde sorg word nie deur organisasies ondersteun nie, terwyl formele tuisgebaseerde sorg wel deur organisasies ondersteun word (McDonnel, Burnham \& Tarantola, 1994:429; Hansen et al. 1998:751; WHO, 2000:8). Vir die doel van hierdie navorsing is tuisgebaseerde sorg die versorging van verswakte MIV- en VIGS-pasiënte in hulle huise deur hulle gesinne.

\section{Primêre versorger}

Wanneer verwys word na primêr, word bedoel eerste. Versorger beteken om te steun en die broodwinner te wees. Die persoon wat versorg, aanvaar verantwoordelikheid om sekere take vir die persoon wat versorg word, te verrig. Dit sluit in persoonlike sorg soos optel, was, hulp na die toilet en alles wat die afhanklike persoon self nie kan doen nie. Die versorger is emosioneel betrokke by die persoon wat versorging ontvang en het 'n verantwoordelikheidsgevoel teenoor hierdie persoon (Twigg \& Atkin, 1994:8-10).

\section{NAVORSINGSMETODOLOGIE}

Om te verseker dat die gesinslede se belewenis ten opsigte van tuisgebaseerde sorg van verswakte MIVen VIGS-pasiënte in die myngemeenskap binne konteks so volledig moontlik beskryf word, is op ' $n$ kwalitatiewe, verkennende, beskrywende navorsingsontwerp besluit. Hierdie ontwerp is volgens Creswell (1994:162) toepaslik in navorsing wat in 'n natuurlike omgewing plaasvind en menslike gedrag en gebeurtenisse verken, soos in hierdie geval. Weens die teenwoordigheid van omvattende myngeriewe in die Klerksdorp-Orkney-Stilfontein-Potchefstroom-Fochvillegebied is die navorsing binne hierdie geografiese grense gedoen. Die populasie het bestaan uit gesinslede as primêre versorgers wat verantwoordelik was vir die tuisversorging van die verswakte MIV- en VIGSpasiënte.

\section{Steekproeftrekking}

Primêre versorgers wat aan geselekteerde kriteria voldoen, is deur middel van tussengangers soos gemeenskapsverpleegkundiges, gemeenskapswerkers en geneeshere geïdentifiseer. 'n Doelgerigte vrywillige steekproef (Burns \& Grove, 1997:306) is getrek. Insluitingskriteria wat gebruik is om te verseker dat hierdie gesinslede ingesluit is en om 'n doelgerigte 
vrywillige steekproef (Burns \& Grove, 1997:306) te neem, was soos volg:

Deelnemers moes:

- 'n verswakte MIV- en VIGS-pasiënt - wat weens die omvang van VIGS-geassosieerde simptome nie meer by die mynmaatskappy werksaam was nie, maar steeds 'n werknemer van 'n mynmaatskappy was - tuis versorg het;

- die primêre versorger van die gesin wees;

- woonagtig wees binne die grense van Klerksdorp, Orkney, Stilfontein, Potchefstroom en Fochville;

- bereid wees om vrywillig aan die navorsing deel te neem;

- toestem dat die onderhoud op oudiokasset opgeneem word;

- oor die kognitiewe en verbale vermoë beskik om tydens die onderhoud sy/haar ervaring te deel; en

- Tswana, Afrikaans of Engels magtig wees.

\section{Data-insameling en data-analise}

Data-insameling is gedoen deur middel van in-diepteonderhoude. Deelnemers is gevra hoe dit vir hulle is om die verswakte MIV- en VIGS-pasiënt te versorg. Die onderhoudvoerder is ' $n$ inheemse taal magtig en beskik oor kommunikasievaardighede wat sy toegepas het om die belewenis van die gesinslede tydens die gesprek te verken. Dataversadiging is na tien onderhoude bereik. Data-analise is gedoen deur 'n onafhanklike medekodeerder en die navorser deur gebruik te maak van 'n kombinasie van die benaderings tot data-analise van Tesch (soos aangehaal deur Creswell, 1994:154155) en Giorgi (soos aangehaal deur Omery, 1983:57$58)$.

\section{Vertrouenswaardigheid}

Volgens Guba (soos aangehaal deur Krefting, 1991:215217 ) is die vier kriteria, naamlik waarheidsgetrouheid, toepaslikheid, konsekwentheid en neutraliteit aangelê om vertrouenswaardigheid te verseker. Geloofwaardigheid is bewerkstellig as strategie om waarheidsgetrouheid te verseker. Die navorser was 'n geruime tyd reeds betrokke by die myngemeenskap as gemeenskapsverpleegkundige wat verlengde betrokkenheid verseker het. Triangulasie het plaasgevind deur navorsing en deur onderhoude aan kundiges voor te lê. 'n Literatuurkontrole is gedoen. 'n Ervare psigiatriese verpleegkundige as onderhoudvoerder het waarnemingseffekte beperk deur van veldnotas gebruik te maak. Digte beskrywings van die navorsingsproses het waarheidsgetrouheid verder bevorder. Toepaslikheid is verseker deur die digte beskrywing van die konteks van die navorsing sodat die navorsing oordraagbaar is. Konsekwentheid is deur vertroubaarheid verseker. Die navorsing is duidelik beskryf en is beskikbaar vir eksterne ouditering. Insluitingskriteria het seleksie van geskikte kandidate verseker. Neutraliteit is deur bevestigbaarheid verseker wat deur middel van noukeurige beskrywing van die proses bereik is.

\section{ETIESE ASPEKTE}

Verskeie outeurs (Brink, 1996:39; DENOSA, 1998:17; Uys \& Basson, 1991:39-47; Sanne, Firnhaber, Jentsch \& Ive, 2000:42) het etiese riglyne gedokumenteer en ' $n$ kombinasie van hierdie riglyne is tydens die uitvoering van hierdie navorsing gehandhaaf. Belangrike etiese beginsels wat tydens die navorsing toegepas is, is die volgende: veiligheid van deelnemers, beskerming van deelnemers se regte en respek vir menswaardigheid. Veiligheid van deelnemers is verseker deur te sorg dat deelnemers vooraf ingelig is. ' $n$ Kundige persoon was beskikbaar tydens onderhoudvoering indien enige deelnemer sou meen dat hulle benadeel word of indien enige ander onderwerp uitklaring sou verg. Navorsing het ook ten doel gehad om die gesin te bemagtig, en dit was dus tot voordeel van die gemeenskap. Deelnemers se regte is beskerm deur die handhawing van konfidensialiteit deur middel van skriftelike versekering. Deelnemers kon ook self die plek van onderhoudvoering aanwys en slegs die nodige inligting is ingesamel, en dit het hulle vrygestaan om hulle te eniger tyd aan die navorsing te onttrek. Respek vir menswaardigheid is verseker deur skriftelike toestemming by die betrokke outoriteite en deelnemers te verkry nadat skriftelik aan die partye verduidelik is wat die navorsing behels. Die verantwoordelikhede van die navorser was om die outonomie van deelnemers te erken, skriftelike terugvoer aan die betrokke instansies te gee, die resultate te publiseer, deursigtigheid te verseker deur' $n$ volledige beskrywing van die navorsing te doen en erkenning aan deelnemers te gee.

\section{BEPERKINGE VAN DIE NAVORSING}


Een van die beperkinge van die navorsing het verband gehou met die geïdentifiseerde geografiese gebied waarbinne die navorsing plaasgevind het. Die voorgeskrewe bepaling van provinsiale grense het gelei tot die uitsluiting van 'n spesifieke myngemeenskap met ' $n$ besondere behoefte aan tuisgebaseerde sorg van die verswakte MIV- en VIGS-pasiënt. ' $n$ Verdere beperking was dat die identifisering van deelnemers vertraag is as gevolg van tussengangers se onkunde ten opsigte van die navorsingsproses en huiwering om pasiënte se MIV-status bekend te maak. Opleiding van tussengangers asook die toepassing van etiese maatreëls het hierdie beperking tot ' $\mathrm{n}$ groot mate opgehef. Taalverskille tussen die navorser, die onderhoudvoerder en die deelnemers het die datainsameling gekompliseer.

\section{RESULTATE EN LITERATUURKON- TROLE}

Drie hoofkategorieë wat die gesin van die verswakte MIV- en VIGS-pasiënt se belewenis beskryf, het uit die navorsing na vore gekom, naamlik: die gesin se belewenis ten opsigte van die versorging van die verswakte MIV-en VIGS-pasiënt; die gesin se belewenis van die gemeenskap se reaksie teenoor die gesin van die MIV- en VIGS-pasiënt; en die gesin se belewenis ten opsigte van die sterwensproses.

Weens die kwalitatiewe aard van die navorsing is 'n literatuurstudie nie vooraf gedoen nie. Literatuurkontrole is tydens die bespreking van die resultate gedoen om resultate te kontroleer en ooreenkomste tussen die literatuur en die bevindings van die navorsing uit te wys, terwyl die uniekheid van bevindinge terselfdertyd uitgelig is (Woods \& Catanzaro, 1998:142).

Resultate ten opsigte van die belewenis van die gesin wat die verswakte MIV- en VIGS-pasiënt in die myngemeenskap versorg, word vervolgens bespreek.

RESULTATE TEN OPSIGTE VAN DIE BELEWENIS VAN DIE GESIN WAT DIE VERSWAKTE MIV- EN VIGS-PASIËNT IN DIE MYNGEMEENSKAP TUIS VERSORG

Die gesin se belewenis ten opsigte van die versorging van die verswakte MIV- en VIGS-pasiënt
Die gesin se belewenis ten opsigte hiervan kon in vier subkategorieë verdeel word, naamlik hulle belewenis van die fisieke, psigiese, sosiale en geestelike dimensies van versorging.

\section{Belewenis ten opsigte van die fisieke dimensie van versorging}

Die gesinne beleef almal die fisieke versorging van die verswakte MIV- en VIGS-pasiënt as moeilik. Hulle verbaliseer dit onder andere soos volg: "It was a bad time" en "(i)t was not easy". Die aspekte wat dit vir hulle moeilik maak, is die volgende:

Gesinne beleef fisieke moegheid as gevolg van fisiek uitputtende aktiwiteite soos die was van die pasiënt, rug- en drukplekversorging, ruil van linne en die massering van die pasiënte. Hulle sal byvoorbeeld noem: "You get tired but I will not get tired for him". Sims en Moss (1991:10) bevestig dat die fisieke versorging van die verswakte MIV-en VIGS-pasiënt'n groot uitdaging is.

Gesinne beleef moedeloosheid wanneer die pasiënte gevoer moet word omdat hulle nie wil of kan sluk nie. Die onvermoë om te sluk gee aanleiding daartoe dat die pasiënt nie sy medikasie neem nie. Dit laat die gesinne hulpeloos voel. Die een versorger spreek haar soos volg uit: “... omdat ek maar mens was, het ek maar moedeloos geraak ... hy wou nie meer sy pille drink nie". Bray en Fruge (2000:36) noem dat die moedeloosheid van versorgers van MIV- en VIGSpasiënte ' $n$ bron van kommer vir gesinne is.

Gesinne ervaar frustrasie omdat die pasiënte nie beheer het oor hulle toiletgewoontes nie, maar verwyt hulleself later oor die feit dat hulle nie genoeg vir die pasiënt gedoen het nie: "... he did everything on the bed and I had to wash everything". Terwyl Cullinan (2001:19) bevestig dat die versorging van die pasiënt ' $n$ belewenis van frustrasie tot gevolg kan hê, maan Sims en Moss (1991:10) versorgers om te waak teen ontoepaslike gevoelens van skuld teenoor die pasiënt.

Aangesien bystand met passiewe en aktiewe oefeninge tyd neem, beleef die gesinne ongeduld met die pasiënte omdat dit somtyds ' $n$ beslommernis is om na hulle om te sien. Die volgende aanhaling bevestig die ongeduld ten opsigte van die pasiënt se mobilisasie: “... sometimes $X$ sleeps and I tell him not to sleep but to exercise just to work in the garden because when you are 
HIV you must not sleep, is not right'. Literatuur bevestig dat mobilisasie ' $n$ belangrike faset van die versorging van die pasiënt is (Stott \& Finlay, 1984:67), sowel as dat versorgers ongeduld kan beleef (Evian, 2000:114).

Die wisselvalligheid van die pasiënt se fisieke toestand bring mee dat die gesin onsekerheid beleef ten opsigte van die hantering van die siektetoestand. ' $n$ Versorger beskryf dit soos volg: "Sometimes he is fine and sometimes he change. You don't understand how you will describe it'. Antle, Wells, Goldie, Dematteo en King (2001:1) beklemtoon dat gesinne onsekerheid kan beleef, aangesien VIGS onvoorspelbare gesondheidsveranderinge tot gevolg het.

Gesinne beleef hospitalisasie van die pasiënte as gevolg van hulle fisieke toestand as 'n ontwrigting omdat die mediese sorg nie die pasiënte se toestand kan verander nie. "En hy was kort-kort in die hospitaal gewees en dit was verskriklik moeilik om in en uit die hospitaal te wees". Bharat en Aggleton (1999:28) is van mening dat, alhoewel hospitalisasie dikwels 'n verligting vir versorgers is, hulle ook die reis tussen die hospitaal en die huis as 'n ekonomiese en fisieke las kan ervaar.

\section{Belewenis ten opsigte van die psigiese dimensie van versorging}

Hierdie belewenis van gesinne wat die verswakte MIVen VIGS-pasiënt in die myngemeenskap versorg, is intens van aard.

As gevolg van die gesin se belewenis van hartseer en pyn omdat hulle die verswakte MIV- en VIGS-pasiënt se pyn en lyding moet aanskou, is die versorging van hierdie pasiënt 'n wroeging vir die gesin. Stiltes ten tye van die onderhoude, sowel as deelnemers wat gehuil het, bevestig die diep hartseer wat die gesinne beleef. Gesinne verbaliseer die volgende: "It was hurting and you know how he used to look like". "It was painful" en "... after I heard that I was crying". Rait, Ross en Rao (1997:249) sowel as Salmon (2002:12) beskryf hierdie hartseer en emosionele pyn van die gesinne as chronies, intens en onmeetlik.

Ondanks die hartseer en pyn beleef die gesin 'n verantwoordelikheidsin vir die ondersteuning en berading van die MIV- en VIGS-pasiënt. Hulle noem dat die pasiënte twyfel aan die lojaliteit van hulle gesinne, en gesinne voel verantwoordelik daarvoor om hulle gerus te stel, te verseker van hulle liefde en te beraad. Hulle sal byvoorbeeld die volgende aan die pasiënt noem: "En so lank as wat ek kan, sal ek jou help" en "I was trying to councel her, to take out the pain and speak to her ...". Evian (2000:114) noem dat ondersteuning en berading een van die verantwoordelikhede van die gesinne is, en dat hierdie ondersteuning net so belangrik as mediese versorging is.

Die gesin beleef ' $n$ gevoel van desperaatheid ten opsigte van die verswakte MIV- en VIGS-pasiënt se gesondheid en probeer hom help. Hulle poog om self kennis op te doen oor MIV en VIGS en gee voorligting aan die pasiënt oor sy siektetoestand en leefwyse in 'n poging om hom te motiveer en hoop te gee. Dit word duidelik uit onder andere die volgende aanhalings van die versorgers: "I tried to talk to him that he must drink his pills or he cannot get better" en "I was guarding that he does not drink or smoke and provided him with some food" en "I always read the pamphlets and I knew how to accommodate her'. Rait et al. (1997:233) bevestig dat gesinne desperaatheid ervaar. Bharat en Aggleton (1999:28) noem verder dat gesinne deur koerante en tydskrifte blaai in die hoop om op 'n kuur af te kom.

Die gesin beleef ongeduld ten opsigte van die pasiënt se buierigheid, vergeetagtigheid en aggressie. Hulle gaan desnieteenstaande voort om die pasiënt te versorg. Ongeduld word in die volgende aanhalings weerspieël: "... het ek party dae gevoel ek gaan hom vermoor, en dit was vir my verskriklik moeilik" en "No one could have coped with his requests?'. Bharat en Aggleton (1999:28) noem eweneens dat die VIGS-pasiënt se buierigheid as ' $n$ las tydens versorging beleef word en dat versorgers vrees beleef weens hulle onvermoë om hierdie buierigheid te hanteer. Daar word nie in literatuur spesifiek melding gemaak van die gesin se ongeduld tydens die versorging van die pasiënt nie.

Gesinne en pasiënte beleef ontkenning ten opsigte van die pasiënte se toestand en agteruitgang. Dit maak dit vir die gesinne moeilik om die pasient se toestand te hanteer. Terwyl gesinne makliker aanvaar dat die pasiënt MIV-positief is, vind hulle dit moeilik om die realiteit van VIGS te aanvaar. Die aanhalings “... toe's dit weer positief. Maar toe't ek dit begin aanvaar en party dae was dit verskriklik moeilik om hom te versorg ..." en "I told her that I still do not believe" beskryf hierdie belewenis. Ontkenning van gesinne ten opsigte van die 
verswakte VIGS-pasiënt se toestand word deur Chinkanda (1990:13) bevestig.

Gesinne beleef emosionele vermoeienis omdat die pasiënt se positiewe MIV-status geheim gehou word en dit gespanne verhoudings tot gevolg het. 'n Moeder noem byvoorbeeld dat haar kind deurgaans vrae stel oor sy vader se siektetoestand en nie kan verstaan wat die probleem is nie. ' $n$ Ander gesinslid noem die volgende: "He was very sick but keeping it a secret. He didn't want to talk out his sickness, so I also get very sick ...". Uit die literatuur blyk dit dat gesinne se openhartigheid en vertroue jeens ander belemmer word deurdat hulle poog om die pasiënt se siektetoestand geheim te hou (Boyd-Franklin, Aleman, Steiner, Drelich \& Bradley, 1995:121). Dit blyk ook dat veral moeders van VIGS-pasiënte poog om die pasiënte se diagnose geheim te hou uit vrees vir diskriminasie (Human, 1993:59; Kreibick, 1995:169).

Gesinne stel hulle bloot aan risikogedrag in 'n poging om die pasiënte daarvan te verseker dat hulle aanvaar word. Dit gee aanleiding tot die belewenis van kommer. Risikogedrag, soos beskryf deur die deelnemers, sluit in om nie handskoene te gebruik wanneer die pasiënt skoongemaak word nie, dieselfde eetgerei te gebruik ondanks die moontlikheid van seertjies in die mond, seksueel te verkeer sonder beskerming en massering van die pasiënt om pyn te verlig ten spyte van die teenwoordigheid van sere. Die volgende aanhaling ondersteun hierdie bevinding: "We used to wash him (her) with our bare hands, not using gloves to show that we care for our sister". Alhoewel daar in literatuur melding gemaak word van die pasiënt se behoefte aan fisieke kontak as bewys van aanvaarding (Barbee, Derlega, Sherburne \& Grimshaw, 1998:94), blyk die gesin se kommer ten opsigte van hulle eie risikogedrag 'n unieke bevinding te wees.

Alhoewel gesinne die pasiënte met liefde versorg, beleef hulle teleurstelling in die pasiënte en ongeloof oor hulle MIV-positiewe status. Die gesin het die pasiënt dikwels gewaarsku ten opsigte van risikogedrag, en die pasiënt vertrou. Die teleurstelling en ongeloof word weerspieël in die volgende aanhalings: "... and she never wanted to listen and I told her that I had to warn her because she was my child ..., so she left and got married to this man" en "I didn't believe. And I know as my husband maybe he had given me that". Literatuur verwys nie spesifiek na hierdie bevinding nie. In verwante literatuur noem Antle et al. (2001:164) dat vrae by gesinslede ontstaan oor hoe die pasiënt VIGS opgedoen het, en het Rait et al. (1997:233) bevind dat gesinne emosies soos skaamte, hartseer, paniek en woede kan ervaar.

\section{Belewenis ten opsigte van die sosiale dimensie van versorging}

Die gesinne beleef 'n verantwoordelikheidsin ten opsigte van die bevordering van sosiale interaksie om die pasiënt se isolasie te voorkom. Die gesin moedig dus sosiale interaksie aan. Die volgende aanhalings bevestig die belewenis: "Because when someone have AIDS she must not stay alone" en "If he was sick I will take him out to visit my friends ...". Currer (2001:41) bevestig dat versorgers dit as besonder belangrik ag om die interpersoonlike belange van die sterwende persoon te handhaaf en te bevorder.

Gesinne beleef skuldgevoelens wanneer goeie familieverhoudinge belemmer word weens die versorging van die pasiënt. Die agteruitgang van die pasiënt dra by tot belemmerde verhoudings. 'n Ma se skuldgevoel kom na vore uit die aanhaling: "... I was trying not to feel that I did wrong thing". Belemmerde verhoudings blyk duidelik uit die volgende aanhaling: "So hy't ons teen mekaar probeer opsteek ook dat ons vir mekaar kan kwaad raak". Rait et al. (1997:215) bevestig dat gesinne wat deur MIV en VIGS geaffekteer word se rol en roetine ontwrig word.

Gesinne beleef ' $n$ begeerte om die kinders wat by die pasiënt betrokke is, teen onder andere onsensitiewe aanmerkings en houdings komende van die gemeenskap te beskerm: "I tried to protect her and my daughter and the kids". Antle et al. (2001:3) sowel as Stein (1997:21) bevestig hierdie bevinding.

'n Belewenis van wedersydse ondersteuning van mekaar verseker samewerking van gesinslede tydens die versorging van die verswakte MIV- en VIGS-pasiënt. Gesinslede los mekaar af ten opsigte van die versorging van die pasiënt. Soms neem kinders die rol van broodwinner aan sodat die primêre versorger tuis kan bly om die pasiënt te kan versorg. Hierdie belewenis word ondersteun deur die volgende aanhalings: "All of us were participating in her illness" en "I had to ask my children to go and work for me". Kreibick (1995:169) bevestig dat gesinslede mekaar ondersteun deur 
bemoediging en die uitvoer van take.

Verantwoordelikheid vir die materiële versorging van die pasiënt en die res van die gesin gee aanleiding tot ' $n$ belewenis van kommer en onsekerheid oor die hede asook oor die toekoms weens finansiële beperkinge. Die verswakte MIV- en VIGS-pasiënt het dikwels afhanklikes wat versorg moet word. Die versorging van die pasiënt het ook bykomende uitgawes tot gevolg. Dit lei tot ' $n$ finansiële las en gepaardgaande kommer en onsekerheid oor die toekoms. Die volgende aanhaling ondersteun hierdie bevinding: "I was wondering how am I going to raise this child because I was not working .... Stein (1997:20) bevestig dat daar'n agteruitgang in die finansiële status van die gesin is, aangesien die pasiënt sowel as die primêre versorger nie meer 'n inkomste genereer nie, en dit kommer tot gevolg het.

\section{Belewenis ten opsigte van die geestelike dimensie van versorging}

Gesinne beleef ' $n$ behoefte aan geestelike leiding omdat die versorging van die pasiënt geestelik uitputtend is. 'n Aanhaling wat hierdie bevinding bevestig, is die volgende: "I like God to help raise him and give him love". Stoter (1995:164) sowel as Evian (2000:299) bevestig dat hierdie gesinne 'n behoefte het aan geestelike ondersteuning.

Die belewenis van volgehoue geloof in 'n Hoër Hand maak dit vir die gesinne moontlik om geduldig te wees met die pasiënt en stel hulle in staat om vol te hou met die versorging van die pasiënt. Een gesinslid stel hierdie geloof soos volg: "Met die hulp van Bo het ek dit, het ek deurgekom". Geloofsopinies kan die gesin se hantering van VIGS bepaal (Rait et al. 1997:242).

'n Sterk geloof maak dit vir die gesin moontlik om sin en betekenis te haal uit die ondervinding om die verswakte MIV- en VIGS-pasiënt te versorg. Die gesin reik uit na ander om te kompenseer vir die swaarkry wat die versorging van die pasiënt meebring. Aanhalings wat hierdie bevinding illustreer, is die volgende: "Dit het van my 'n beter mens gemaak" en "Dan voel ek in my hart goed, want ek kon vir die mense ietsie beteken". Antle et al. (2001:5), Barbee et al. (1998:94) sowel as Mokone (1999:135) bevestig hierdie bevinding.

Die gesin se belewenis van die gemeenskap se reaksie teenoor die gesin

\section{van die MIV- en VIGS-pasiënt}

Die gesin het negatiewe en positiewe belewenisse ten opsigte van reaksies komende van die gemeenskap.

\section{Negatiewe belewenisse}

Aanhalings wat dit bevestig is onder andere die volgende: "... is 'n klein plekkie en as mense hoor van so iets dan verstoot hulle jou"; "They believe they can get AIDS from the funeral' en "... they take that that person was a bad person or your family".

Die onvermoë om sosiaal te verkeer bring mee dat die gesin isolasie van die gemeenskap beleef. Die gesin beleef dat hulle nie oor die pasiënt se toestand kan praat nie, en dit gee aanleiding tot sosiale uitsluiting. Een gesinslid het byvoorbeeld die volgende genoem: "... as mense hoor van so iets dan verstoot hulle jou". Literatuur bevestig dat gesinne geïsoleerd mag voel as gevolg van sosiale uitsluiting, veral weens die vrees vir en onkunde oor VIGS en die oordrag daarvan (Sims \& Moss, 1991:82).

Gesinne beleef ook stigmatisering. Hulle voel dat sleg van hulle gedink word indien die gemeenskap sou uitvind dat hulle 'n MIV-en VIGS-pasiënt versorg. Die volgende aanhaling staaf hierdie bevinding: "They think like if I visited X I am going to get HIV or when I take the cup and drink water'. Strydom (2002:131) bevestig hierdie bevinding.

Gesinne beleef etikettering omdat hulle gekenmerk word as minder goed omdat hulle 'n gesinslid versorg wat MIV en VIGS het. 'n Gesinslid verbaliseer hierdie belewenis as volg: "They take that that person was a bad person or your family". VIGS word geassosieer met verkeerde dade (Webb, 1997:172), en gesinne word wel geëtiketteer op grond daarvan dat 'n gesinslid MIV en VIGS het (Human, 1993:59).

Die gemeenskap aanvaar nie die gesin van die verswakte MIV- en VIGS-pasiënt as deel van die gemeenskap nie, wat' $n$ belewenis van verwerping by die gesin meebring. Verwerping sluit die verwerping deur professionele persone soos mediese personeel in. Die volgende aanhaling ondersteun dit: "They told me they can not take my daughter for admission". Hierdie verwerping word deur Stein (1997:22) bevestig, veral wanneer die pasiënt se toestand nie meer verswyg kan word nie. 
Die gesin beleef vermyding deur die gemeenskap wanneer die gemeenskap nie graag kontak maak met die verswakte MIV- en VIGS-pasiënt en sy gesin nie. 'n Gesinslid verwoord die belewenis as volg: "... then some people know that she is HIV, they avoid her'. Leary en Schreindorfer (1998:12) noem dat hierdie vermyding 'n pynlike ervaring kan wees.

Die gesin beleef ongelukkigheid oor onsensitiewe reaksies komende van die gemeenskap. Lede van die gemeenskap laat die gesinne van die verswakte MIVen VIGS-pasiënt ongelukkig voel weens aanmerkings wat hulle maak. Die volgende aanhaling illustreer hierdie bevinding: "Sometimes they are passing some remarks". Webb (1997:167) noem dat hierdie reaksie van die gemeenskap 'n universele verskynsel is.

\section{Positiewe belewenisse}

Die gesin beleef betroubare ondersteuningsbronne as bevorderlik. Dit vergemaklik die tuisversorging van die verswakte MIV- en VIGS-pasiënt. Bronne wat hiertoe bydra, is: kliniekpersoneel, geestelike leier/kerk, huisdokter, fisioterapeut, kollegas, kankervereniging of ondersteuningsaksies en familielede. 'n Gesinslid het die volgende genoem: "So ek het baie mense gehad tot my beskikking wat my kon help as ek nie meer verder kon nie". Human (1993:59) bevestig dat direkte familielede en professionele persone nuttige bronne van ondersteuning vir die gesin is.

\section{Die gesin se belewenis ten opsigte van die sterwensproses}

Gesinne van die pasiënt beleef vrees en angstigheid ten opsigte van die dood. Alhoewel die gesinne besef dat dit onvermydelik is, is gesinne bang om die laaste oomblikke saam met die pasiënt deur te bring: “... sometimes I would be afraid to be with him". Evian (2000:294) bevestig dat gesinne dikwels die onbekende (dood) meer vrees as die bekende.

Gesinne beleef pyn en hartseertydens die verskillende fases van die sterwensproses. Die volgende aanhaling beskryf die pyn en hartseer: "It was very painful. The only thing I was thinking of was his death". Rait et al. (1997:237) is van mening dat die dood van die pasiënt uiters pynlik vir die gesin is.

Gesinne beleef opstandigheid ten opsigte van die dood en word met tye kwaad. Gesinne word aggressief teenoor die pasiënt. ' $n$ Versorger is selfs kwaad omdat sy die pasiënt moes begrawe. Een versorger het die volgende gesê: "Ag man as jy nou nie jou pille wil drink nie, dan vrek jy maar". Hierdie bevinding blyk uniek aan hierdie navorsing te wees.

As gevolg van die pasiënt se wisselende toestand beleef gesinslede onsekerheid oor wanneer die dood te wagte kan wees. Stellings soos die volgende reflekteer die onsekerheid: "Sometimes she get real ill and you think she is going to die whenever. Sometimes she is fine and sometimes she change". Literatuur bevestig die onvoorspelbaarheid van die oomblik van dood van die MIV- en VIGS-pasiënt (Sims \& Moss, 1991:44; Winiarski, 1991:30).

Omdat gesinslede verantwoordelik is vir sterwensbegeleiding van die pasiënte, beleef hulle 'n gevoel van lojaliteit en staan hulle die persone in hulle laaste tye by: "This was my work and I never got tired of it" en "As she was dedicated to do whatever for him". Fouché en De Vos (1995:304) het bevind dat gesinslede hulle daarvoor beywer dat die VIGS-pasiënt met 'n gevoel van innerlike tevredenheid sterf.

Saam met die dood kom berusting vir die gesin omdat dit 'n verligting van die pasiënt se lyding beteken. Hulle verbaliseer onder andere die volgende: "I felt better and accepted, because she was suffering and sick for eleven years". Currer (2001:38) bevestig hierdie bevinding.

\section{GEVOLGTREKKINGS}

Dit is vir die gesin van die verswakte MIV- en VIGSpasiënt fisiek uitputtend om na hierdie pasiënt om te sien. Verder is die teenwoordigheid van intense belewenisse soos hartseer en pyn, ongeduld, desperaatheid en vermoeienis ' $n$ aanduiding van die psigiese spanning wat gesinne tydens die versorging van die verswakte MIV- en VIGS-pasiënt beleef. Die versorging van die verswakte MIV- en VIGS-pasiënt gee ook aanleiding tot sosiale wanfunksionering van die gesin binne die gemeenskap. Gesinne vind dat hierdie reaksies die versorging van die verswakte MIV- en VIGSpasiënt belemmer. Die fasiliterende reaksies van die gemeenskap is egter vir die gesinne baie waardevol, en dié reaksies is bevorderlik vir die tuisversorging van 
die verswakte MIV- en VIGS-pasiënt.

Onkunde rakende die hantering van die dood gee aanleiding tot gesinne se belewenis van vrees en angstigheid ten opsigte van die sterwensproses. Hulle ervaar ook ' $n$ meer intense hartseer wanneer gesinsverhoudinge belemmer is. Gesinne van die verswakte MIV-en VIGS-pasiënte voel opstandig weens die omstandighede waaronder hulle die pasiënt ten tye van die naderende dood moet versorg. Hulle voel onvoorbereid op die sterwensproses, en dit laat hulle ontoereikend voel. Die gevoel van ontoereikendheid gee weer aanleiding tot die belewenis van onsekerheid. Onkunde oor die verloop van VIGS speel ook 'n belangrike rol by die gesin se belewenis van die naderende dood. Ondanks die negatiewe belewenisse is die gesin steeds lojaal teenoor die verswakte MIVen VIGS-pasiënt en ag hulle dit hulle plig om die verswakte MIV- en VIGS-pasiënt by te staan en sterwensbegeleiding te doen. Die mate van berusting by die gesinne word bepaal deur die kwaliteit van die verhouding wat die pasiënte met hulle gesinne gehad het.

\section{RIGLYNE NA AANLEIDING VAN DIE GEVOLGTREKKINGS}

Algemene riglyne vir die gemeenskapsverpleegkundige waarvolgens die gesin van die verswakte MIV- en VIGSpasiënt bemagtig kan word, is neergelê. Hierdie riglyne is aan die hand van die verpleegproses, 'n doelgerigte sikliese proses (Clark, 1996:77), naamlik van beraming, beplanning, implementering en evaluering ontwikkel.

\section{Algemene riglyne}

Die eerste stap in die proses van bemagtiging van die gesin van die verswakte MIV- en VIGS-pasiënt is om die behoeftes van die gesin te beraam. Alvorens dit egter kan geskied, is dit belangrik dat die gemeenskapsverpleegkundige vooraf reeds 'n vertrouensverhouding met die gesin opgebou het. Sodra 'n vertrouensverhouding bewerkstellig is, kan die volledige beraming van die gesin van die verswakte MIVen VIGS-pasiënt afgehandel word. Ten einde die effektiwiteit van doelwitte en resultate van tuisgesondheidsorg te verseker moet die fokus van tuisgebaseerde gesondheidsorg op die kliënt gerig wees (Cookfair, 1991:416). Dit is dus belangrik dat die gemeenskapsverpleegkundige in samewerking met die gesin beplan en dat die gemeenskapsverpleegkundige alle beskikbare bronne wat vir die gesin van die verswakte MIV- en VIGS-pasiënt van hulp kan wees om genoemde pasiënt tuis te versorg en te mobiliseer, inspan. Dit mag wees dat die gemeenskapsverpleegkundige alternatiewe wyses vanuit die gesin se spesifieke behoeftes identifiseer om die gesin van die verswakte MIV- en VIGS-pasiënt te bemagtig, maar Clark (1996:378) beklemtoon dat kommunikasie met die gesin ten opsigte van hierdie alternatiewe belangrik is. Die suksesvolle implementering van wyses om die gesinne te bemagtig vereis kennis aangaande gemeenskapsorg en beradingsvaardighede. Die evaluering van die proses om die gesin van die verswakte MIV- en VIGS-pasiënt te bemagtig, behoort deurlopend plaas te vind. Gesinne behoort, soos tydens die ander stappe van die verpleegproses, by die evaluering ingesluit te word (Clark, 1996:85). Akkurate dokumentasie moet tydens die verpleegproses aandag geniet. Gemeenskapsverpleegkundiges se evaluering van die uitkoms ten opsigte van spesifieke doe/witte asook hulle evaluering van die proses beïnvloed besluite ten opsigte van verdere verpleegsorg (Clark, 1996:88).

\section{Spesifieke riglyne}

Spesifieke riglyne na aanleiding van resultate aangaande die belewenisse van die gesinne van die verswakte MIVen VIGS-pasiënt in die myngemeenskap is geformuleer.

\section{RIGLYNE VIR DIE GEMEENSKAPS- VERPLEEGKUNDIGE TEN OPSIGTE VAN DIE BEMAGTIGING VAN DIE GESIN VIR DIE VERSORGING VAN DIE VERSWAKTE MIV- EN VIGS-PASIËNT}

\section{Riglyn 1}

Sims en Moss (1991:10) beveel aan dat gesinslede aangemoedig moet word om deurlopend die sleutelpersoon te wees met betrekking tot die versorging van die VIGS-pasiënt, wat beteken dat die besluite ten opsigte van die versorging steeds by die gesin moet berus. Die gemeenskapsverpleegkundige moet daarteen waak om besluite namens die gesinne te neem.

Om fisieke uitputting van die versorger te voorkom, 
behoort die gemeenskapsverpleegkundige voorligting aan die gesin te gee ten opsigte van die belangrikheid van hulle eie gesondheid.

Die vroegtydige beplanning van bystand vir die gesin in die terminale sorg deur 'n gespesialiseerde diensverskaffer soos Hospice sal gesinne die versekering gee dat tydelike versorging wel beskikbaar is wanneer fisieke uitputting onuithoudbaar word (Stott \& Finlay, 1984:69).

Hulpverlening aan versorgers ten opsigte van huishoudelike take verlig dikwels druk wat fisieke uitputting verminder (Stott \& Finlay, 1984:69). Die gemeenskapsverpleegkundige kan vrywillige werkers betrek deur byvoorbeeld werklose jongmense tydens tuisbesoeke saam te neem.

\section{Riglyn 2}

Die sielkundige en emosionele sorg en ondersteuning van gesinne van verswakte MIV- en VIGS-pasiënte is dikwels omvangryk (Sims \& Moss, 1991:77), en vanweë verafgeleë landelike gebiede en die kostefaktor betrokke by die konsultasie van professionele personeel kan gesinne nie altyd deur gekwalifiseerde beraders of sielkundiges gehelp word nie. Gemeenskapsverpleegkundiges behoort dus te verseker dat hulle bekwaam is om effektiewe berading te doen.

Winiarski (1991:105) noem dat dit moontlik nodig kan word om die gesinne van die verswakte VIGS-pasiënt na 'n ander terapeut te stuur indien botsende belange voorkom tydens die berading van beide die pasiënt en gesinslede met byvoorbeeld verskillende sienswyses. Indien dit nodig blyk te wees, kan gebruik gemaak word van alternatiewe soos ander lede van die multidissiplinêre span, byvoorbeeld die maatskaplike werker.

Ondersteuningsgroepsessies kan van waarde wees aangesien die groep hulle gevoelens daar kan lug. Die gemeenskapsverpleegkundige moet gesinne van die verswakte MIV- en VIGS-pasiënt inlig ten opsigte van hulpbronne soos Life-Line en psigiatriese gemeenskapsdienste wat berading gratis aanbied.

\section{Riglyn 3}

John en Ndebbio (2002:62) bevestig dat die stigma, en ook die vrees vir besmetting met MIV en VIGS, goeie gesinsverhoudinge belemmer. Deur middel van berading en voorligting kan die gemeenskapsverpleegkundige gesinsverhoudinge fasiliteer.

Deur lede van die multi-dissiplinêre span te betrek kan die gemeenskapsverpleegkundige die gesin bystaan met betrekking tot die hantering van spesifieke behoeftes soos behuising en toegang tot finansiële hulp of 'n oefenprogram wat die gesin tuis met die verswakte MIV- en VIGS-pasiënt kan volg.

Die organisering van ondersteuningsgroepe vir die gesin kan hulle help om met ander persone in dieselfde situasie as hulle te kan identifiseer. Die gemeenskapsverpleegkundige kan bydra tot die realisering hiervan deur 'n ondersteuningsgroep te organiseer. Vrywilligers kan opgelei word in die hantering van groepe sodat ondersteuningsgroepsessies in die gesinne se eie taal en kultuur aangebied word.

Gesinne behoort goeie vriende en familielede te vra om gereeld besoek by die verswakte MIV-en VIGS-pasiënte af te lê, omdat dit moeilik is om die pasiënte uit te neem. Gemeenskapsverpleegkundiges kan gesinne aanmoedig om hulle familielede aan hulle voor te stel wanneer die gemeenskapsverpleegkundiges besoeke aflê. Die familielede wat huiwer om besoek af te lê sal veiliger voel en kan aangemoedig word om dit wel te doen.

Alhoewel dit nie altyd moontlik is om materiële bystand in die vorm van geld of benodigdhede aan gesinne te verleen nie, kan die gemeenskapsverpleegkundige voorligting gee oor alternatiewe versorgingshulpmiddels.

\section{RIGLYNE AAN DIE GEMEENSKAPS- VERPLEEGKUNDIGE TEN OPSIGTE VAN DIE GESIN SE BELEWENIS VAN DIE GEMEENSKAP SE REAKSIE TEENOOR DIE GESIN VAN DIE MIV- EN VIGS- PASIËNT}

\section{Riglyn 1}

Die mate van stigmatisering word beïnvloed deur die opvoedingsvlak van die gemeenskap (Conradie \& Rabie, soos aangehaal deur Webb, 1997:177). Dlamini (1993:5) bevestig dat etikettering ten opsigte van MIV en VIGS 
algemeen voorkom en dat dit teëgewerk kan word deur middel van uitgebreide voorligting. Funk (1994:18) noem verder dat die stigmatisering en verwerping van VIGSpasiënte deur die gemeenskap hartseer en eensaamheid tot gevolg het. Daarom behoort die opheffing van onkunde deur middel van voorligting belemmerende reaksies van die gemeenskap teenoor die MIV-en VIGS-pasiënt en sy gesin te verminder.

Voorligting kan op verskillende maniere plaasvind:

Onkunde van die gemeenskap kan deur middel van inligtingsveldtogte verminder word. ' $n$ Voorbeeld hiervan is die Mothusipilo-projek in Carletonville (Williams et al. 2000:358) wat daadwerklik inligtingsveldtogte laat realiseer deur selfs van die media soos televisie en die radio gebruik te maak.

Groter maatskappye, soos dié van die mynmaatskappye, kan vir finansiële bystand genader word om te verseker dat sulke veldtogte 'n positiewe indruk op die gemeenskap laat. Anglogold bied byvoorbeeld beradingsprogramme vir hulle werknemers aan (Kahn, 2002:2).

As rolmodel kan die gemeenskapsverpleegkundiges ' $n$ voorbeeld aan die gemeenskap stel deur nie te huiwer om besoek by gesinne wat verswakte MIV- en VIGSpasiënte versorg, af te lê nie. Hulle kan ook deur die motivering van vrywilligers die boodskap na die gemeenskap uitdra dat sodanige ondersteuning baie vir sulke gesinne beteken.

\section{Riglyn 2}

Riglyne ten opsigte van die belewenis van fasiliterende reaksies van die gemeenskap sou wees om hierdie fasiliterende reaksies te ondersteun en verder te fasiliteer. Dit kan gedoen word deurdat die gemeenskapsverpleegkundige byvoorbeeld tuisbesoeke aan vriende en familie van die verswakte MIV- en VIGSpasiënte bring.

Voortdurende indiensopleiding van gesondheidspersoneel ten opsigte van die behoeftes van die gesinne van die verswakte MIV- en VIGS-pasiënt kan die fasiliterende reaksies van gesondheidspersoneel bevorder.

Die bevordering van 'n multi-dissiplinêre benadering deur die gemeenskapsverpleegkundige kan fasiliterende reaksies deur professionele persone as lede van die gemeenskap bevorder, omdat gesinne sal voel dat die multi-dissiplinêre span as geheel hulle wil ondersteun.

\section{RIGLYNE VIR DIE GEMEENSKAPS- VERPLEEGKUNDIGE TEN OPSIGTE VAN DIE GESIN SE BELEWENIS VAN DIE STERWENSPROSES}

\section{Riglyn 1}

Aaangesien sterwende persone bewus is van die agteruitgang van hulle eie gesondheid, is gesinne dikwels bang vir die verandering wat vir hulle voorlê (Stott \& Finlay, 1984:5). Stott en Finlay (1984:5) beveel in dié verband aan dat die pasiënte en hulle gesinne toegelaat moet word om die dokter of verpleegkundige so dikwels as wat nodig mag wees, te konsulteer. Die gemeenskapsverpleegkundige of ' $n$ ander lid van die multidissiplinêre span, soos die maatskaplike werkster, behoort beskikbaar te wees vir sulke konsultasies.

Gesinne behoort toegelaat te word om hulle emosies verbaal of nie-verbaal teenoor 'n onafhanklike persoon uit te druk, selfs al sou dit die herhaling van spesifieke kwessies insluit (Stott \& Finlay, 1984:5). Gemeenskapsverpleegkundiges moet dus geredelik beskikbaar wees vir sulke geleenthede. Hulle moet ook daarop voorbereid wees dat dit die gesin moontlik tyd kan neem voordat hulle hul emosies openbaar sal maak, en dat dieselfde kwessies moontlik herhaal sal word.

Die hantering van 'n onvoltooide rouproses sluit in om te luister, emosionele ondersteuning te gee en die verwysing na toepaslike bronne (Valfre, 2001:217). Die gemeenskapsverpleegkundige sal waarskynlik die eerste persoon wees wat die onvoltooide rouproses sal waarneem. Deur na die persoon te luister kan die behoeftes van die persoon wat treur, bepaal word, en die aanmoediging van persone om gevoelens te lug is die begin van die helingsproses (Valfre, 2001:217).

\section{Riglyn 2}

Volgens Penson (1995:278) word die rouproses vir sommige persone belemmer deur faktore soos "onafgehandelde besigheid" of onopgeklaarde konflik. Gemeenskapsverpleegkundiges behoort oor beradingsvaardighede te beskik wat sulke persone tot 
'n realiteitsbesef kan lei. Hulle moet dus die gesin emosioneel kan ondersteun sonder om byvoorbeeld die feit dat die verswakte pasiënt terminaal is, te ontwyk.

'n Deeglike kennis van ander ondersteuningsbronne vir die gesin wat rou, kan die gemeenskapsverpleegkundige in staat stel om hulp, soos die beskikbaarheid van bekostigbare begrafnisdienste vir gesinne, voor te stel (Penson, 1995:279).

\section{Riglyn 3}

Sims en Moss (1991:88) bevestig dat misplaaste woede en 'n gevoel van magteloosheid by die persone wat rou soms teenoor ander persone geuiter word en dat gesinne met tye aggressief teenoor die gemeenskapsverpleegkundige mag optree. Dit is dus vir die gemeenskapsverpleegkundige raadsaam om nie ontstelde roubeklaers een-een te hanteer nie en 'n kollega uit die multi-dissiplinêre span, byvoorbeeld die maatskaplike werkster, na die gesin saam te neem.

Woede ontstaan wanneer individue nie daarin slaag om beheer oor hulleself, hulle omgewing en spesifieke situasies uit te oefen nie (Perko \& Kreigh, 1988:357). Dieselfde is van toepassing op die gesin se belewenis van aggressie en opstandigheid. Perko en Kreigh (1988:357) beveel aan dat die verpleegkundige aggressiewe persone moet help om hulle woede te identifiseer en sosiaal aanvaarbare maniere moet vind om die woede te hanteer.

\section{Riglyn 4}

Sims en Moss (1991:82) bevestig dat persone wat voorbereid is op die dood waarskynlik die omstandighede beter sal hanteer en noem dat die rol van ondersteuningsgroepe nie onderskat moet word nie. Die organisering van ondersteuningsgroepe deur die gemeenskapsverpleegkundige wat ten nouste betrokke is by die gesinne van verswakte MIV- en VIGS-pasiënte, behoort dus die onsekerheid en onkunde oor die naderende dood by gesinne van die verswakte MIV- en VIGS-pasiënt te kan verlig.

Sims en Moss (1991:82) beveel verder aan dat ondersteuning in die rouproses reeds voor die dood behoort te begin.

\section{Riglyn 5}

Positiewe belewenisse van die sterwensproses, soos die belewenis van lojaliteit, behoort versterk te word. Deur gesinne wat die versorging van die verswakte MIVen VIGS-pasiënt positief ondervind het aan te moedig om na gesinne wat ondersteuning nodig het uit te reik, sal die positiewe ondervinding versterk word.

Effektiewe voorligting ten opsigte van sterwensbegeleiding kan verseker dat gesinne wel belewenisse van lojaliteit teenoor die verswakte MIV- en VIGS-pasiënt ervaar.

\section{Riglyn 6}

Indien die gemeenskapsverpleegkundige effektiewe berading kan toepas, behoort sy in staat te wees om die gesinne te lei om self sterwensbegeleiding te doen wat dan tot berusting sal lei.

\section{SAMEVATTING}

Tydens die navorsing is daarin geslaag om ' $n$ breedvoerige verkenning en beskrywing te gee van die gesin se belewenis ten opsigte van tuisgebaseerde sorg van die verswakte MIV- en VIGS-pasiënt in die myngemeenskap. Aan die hand van die resultate is riglyne vir die gemeenskapsverpleegkundige geformuleer om gesinne van verswakte MIV- en VIGSpasiënte te bemagtig ten einde tuisgebaseerde sorg aan hierdie pasiënt te bevorder. Hiermee is die doelstellings van die navorsing suksesvol bereik.

Resultate van die navorsing bring insig in die belewenis van die gesin wat die verswakte MIV- en VIGS-pasiënt tuis versorg. Gevolgtrekkings wat gemaak word, is dat die gesinne van die verswakte MIV- en VIGS-pasiënte tydens hulle tuisversorging ' $n$ behoefte het aan uitgebreide ondersteuning deur gesinslede en die gemeenskap. Gesinne vind die versorging moeilik vanweë ' $n$ verskeidenheid redes, maar waarskynlik is die belangrikste die fisieke, psigiese, sosiale en geestelike eise wat die versorging aan hulle stel.

\section{ERKENNING}

Hierdie artikel is gebaseer op navorsing wat deur die "National Research Foundation" ondersteun is 
(verwysingsnommer GUN2050275). Enige menings, bevindinge en gevolgtrekkings of aanbevelings in hierdie artikel is dié van die outeur(s) en weerspieël nie noodwendig die beskouing van die "National Research Foundation" nie.

\section{BRONNELYS}

ANTLE, B; WELLS, LM; GOLDIE, RS; DEMATTEO, D \& KING, SM 2001: Challenges of parenting for families living with HIV/AIDS. Social Work, 46(2):159-170. (In: EBSCOHost: Comprehensive MEDLINE, Full display: http://www-sa.ebsco.com) (Date of access: 7 March 2001).

BARBEE, AP; DERLEGA, VJ; SHERBURNE, SP \& GRIMSHAW, A 1998: Helpful and unhelpful forms of social support for HIV-positive individuals. (In: Derlega, VJ \& Barbee, AP eds. 1998: HIV and social interaction. Thousand Oaks: Sage, pp 83-105).

BEERS, MH \& BERKOW, R, eds. 1999: The Merck manual of diagnosis and therapy $2001 ; 17^{\text {th }}$ edition. Whitehouse station: Merck Research Laboratories.

BHARAT, S \& AGGLETON, P 1999: Facing the challenge: Household responses to HIV/AIDS in Mumbai, India. AIDS Care, 11(1):3144. (In: EBSCOHost: Comprehensive MEDLINE, Full display: http:/ /www-sa.ebsco.com) (Date of access: 7 March 2001).

BOYD-FRANKLIN, N; ALEMAN, J; STEINER, GL; DRELICH, EW \& BRADLEY, CN 1995: Family systems interventions and family therapy. (In: Boyd-Franklin, N, Steiner, L \& Boland eds. 1995: Children, families and HIV/AIDS: Psychosocial and therapeutic issues. New York: Guildford, pp 179-198).

BRAY, JH \& FRUGE, E 2000: Assessment and evaluation of HIV/ AIDS families: Applications to prevention and care. (In: Pequegnant, W \& Szapocznik, J eds. 2000: Working with families in the era of HIV/AIDS. Thousand Oaks: Sage, pp 27-44).

BRINK, HI 1996: Fundamentals of research methodology for health care professionals. Cape Town: Juta.

BURNS, N \& GROVE, SK 1997: The practice of nursing research: Conduct critique and utilization; $3^{\text {rd }}$ edition. Philadelphia: WB Saunders.

CHINKANDA, E 1990: Some psychological issues regarding the care of AIDS patients. Social Work Practice, 1990(2):12-14. CLARK, MJ 1996: Nursing in the community; $2^{\text {nd }}$ edition. Stanford: Appleton \& Lange.

COOKFAIR, JM 1991: Home health care and chronic illness. (In: Darlene Como, N, ed. 1991: Nursing process and practice in the community. St. Louis : CV Mosby, pp 407-417).

CRESWELL, JW 1994: Research design: Qualitative and quantitative approaches. Thousand Oaks: Sage.

CULLINAN, K 2001: Sent home to die. AIDS Bulletin, 10(1):19.

CURRER, C 2001: Responding to grief: Dying, bereavement and social care. New York: Palgrave.

DENOSA (Democratic Nursing Organisation of South Africa) 1998: Letter to university nursing science departments, nursing colleges, technikons and nursing schools regarding ethical standards for nurse researchers, 5 March 1998. Pretoria. (Copy in possession of the author).

DLAMINI, M 1993: Women as caregivers - An interview with clinic sister, M Dlamini. AIDS Bulletin, 2(1):4-5.

EVIAN, C 2000: Primary AIDS care: A practical guide for primary health care personnel in clinical and supportive care of people with HIV/AIDS. Houghton: Jacana Education.

FACT SHEETS ON HIV/AIDS 2000: Pretoria: Department of Health. FOUCHE, CH \& DE VOS, AS 1995: Hulpverlening aan persone met HIV-infeksie. Social Work, 31(4):293-304.

FUNK, B 1994: Counselling the dying patient: Some issues in terminal councelling. AIDS Bulletin, 3(4):18-19.

HAILE, B 2000: Affordability of home-based care for HIV/AIDS. South African Medical Journal, 90(7):690.

HANSEN, K; WOELK, G; JACKSON, H; KIRKHOVEN, R; HANJONJORI, N; MARAMBA, P; MUTAMBIRWA, J; NOLIMANDE, E \& VERA, E 1998: The cost of home-based care for HIV/AIDS patients in Zimbabwe. AIDS Care, 10(6):751-759. (In: EBSCOHost: Comprehensive MEDLINE, Full display: http://-sa.ebsco.com) (Date of access: 7 March 2001).

HUMAN, C 1993: Source and nature of social support recelved after death of an adult child as result of AIDS or cancer: A comparison of mothers' perceptions. UNISA Psychologia, 20(1):5560.

JOHN, ME \& NDEBBIO, TJ 2002: Perceived psychological needs, social support, quality of life, and adjustment in subjects with HIV/ AIDS. African Journal of Nursing and Midwifery, 4(1):59-62. KAHN, T 2002: Anglogold confronts health care in the AIDS era. Business Day, 2 April 2005.

KREFTING, L 1991: Rigor in qualitative research: The assessment of trustworthiness. American Journal of Occupational Therapy, 45(3):214-222.

KREIBICK, T 1995: Caretakers' support group. (In: Boyd-Franklin, N; Steiner, L \& Boland, M eds. 1995: Children, families and HIV/ AIDS: Psychosocial and Therapeutic Issues. New York: Guildford, pp 325).

LEARY, MR \& SCHREINDORFER, LS 1998: The stigmatisation of HIV and AIDS: Rubbing salt in the wound. (In: Derlega, VJ \& Barbee, AP eds. 1998: HIV and social interaction. Thousand Oaks: Sage, pp 12-29).

MCDONNEL, S; BURNHAM, M \& TARANTOLA, D 1994: Assessing and planning home-based care for persons with AIDS. Health Policy and Planning, 9(4):429-437.

MOKONE, JM 1999: The role played by the family as a support system for the elderly and the challenges of caregiving. Social 
Work, 35(2):133-137.

ODENDAL, FF \& GOUWS, RH 2000: Verklarende Woordeboek van die Afrikaanse Taal; $4^{\text {de }}$ uitgawe. Midrand: Perskor.

OMERY, A 1983: Phenomenology: A method for nursing research.

Advances in Nursing Science, 5(2):49-63.

PENSON, J 1995: Caring for bereaved relatives. (In: Penson, J \&

Fisher, R eds. 1995: Palliative care for people with cancer; $2^{\text {nd }}$ edition. London: Arnold, pp 269- 281).

PEQUEGNANT, W \& SZAPOCZNIK, J 2000: The role of families in preventing and adapting to HIV/AIDS: Issues and answers. (In: Pequegnant, W \& Szapocznik, J eds. 2000: Working with families in the era of HIV/AIDS. Thousand Oaks: Sage, pp 1-3).

PERKO, JE \& KREIGH, HZ 1988: Psychiatric and mental health nursing: A commitment to care and concern; $3^{\text {rd }}$ edition. London: Prentice-Hall International.

RAIT, DS; ROSS, JM \& RAO, SM 1997: Treating couples and families with HIV: A systematic approach. (In: O'Connor, MF ed. 1997: Treating the psychological consequences of HIV. San Francisco: Josey-Boss, pp 225-268).

SALMON, KE 2002: A nursing response to the AIDS crisis. African Journal of Nursing and Midwifery, 4(1):12-14.

SANNE, I; FIRNHABER, C; JENTSCH, U \& IVE, P 2000: Ethics and HIV in South Africa. Southern African Journal of HIV Medicine, $1(1): 42$.

SCHNEIDER, H \& RUSSEL, M 2000: Models of community-based HIV/AIDS care and support in South Africa. South African Journal of HIV Medicine, 1(1):214-216.

SCHOPPER, D \& WALLEY, J 1992: Care for AIDS patients in developing countries: A review. AIDS care, 4(1):89. (In: EBSCO Host: Comprehensive MEDLINE, Full display: http://www-sa.ebsco.com) (Date of access: 7 March 2001).

SIMS, R \& MOSS, VA 1991: Terminal care for people with AIDS. London: Edward.

STEIN, J 1997: The impact of HIV/AIDS on the household. AIDS Bulletin, 6(4):20-23.

STOTER, D 1995: Spiritual care. (In: Penson, J \& Fisher, R eds. 1995: Palliative care for people with cancer; $2^{\text {nd }}$ edition. London: Arnold, pp158-168).

STOTT, NCH \& FINLAY, IG 1984: Care of the dying. Edinburgh: Churchill Livingstone.

STRYDOM, H 2002: Social work research on the feelings and perceptions of AIDS patients in a South African clinic. Social Work, 38(2):131-153.

TWIGG, J \& ATKIN, K 1994: Carers' perceived policy and practice in informal care. Philadelphia: Open University Press.

UYS, HHM \& BASSON, AA 1991: Navorsingsmetodologie in die verpleegkunde; $2^{\text {de }}$ uitgawe. Bloemfontein: HAUM-Tersiêr.

VALFRE, MM 2001: Foundations of mental health care; $2^{\text {nd }}$ edition. St. Louis: CV Mosby.
WEBB, D 1997: HIV and AIDS in Africa. London: Pluto.

WHO (World Health Organization). 2000: Home-based longterm care: Report of a WHO study group. Geneva: WHO.

WILLIAMS, BG; MACPHAIL, C; TALJAARD, D; GOUWS, E; MOEMA, S; MZIDUME, Z \& RASEGO, B 2000: The Carletonville-Mothusimilo Project. Limiting transmission of HIV through community-based interventions. South African Journal of Science, 96(6):351359.

WILLIAMS, B \& CAMPBELL, C 1998: HIV/AIDS in the mining industry: The Carletonville Project. AIDS Bulletin, 7(1):27-28.

WINIARSKI, M 1991: AIDS related psychotherapy. New York: Pergamon.

WOODS, NF \& CATANZARO, M 1998: Nursing research: Theory and practice. St. Louis: CV Mosby. 